\title{
A NEW ANALYSIS OF KALBAK TAŠ I (A-23) INSCRIPTION
}

\author{
HÜLYA YILDIZ \\ Department of Turkish Language and Literature, Faculty of Humanities, Anadolu University \\ Yunus Emre Campus, Office No. C-303, Eskişehir, Turkey \\ e-mail: hkoprulu@anadolu.edu.tr
}

This paper focuses on Kalbak-Taš I inscription which belongs to the Mountainous Altai group. It provides an analysis of the problematic issues of the inscription that have emerged in previous studies, as well as some new reading proposals for some parts of the inscription. The transliterations of Kalbak-Taš I given by the previous researchers differ from one another regarding some sign decipherments. Our study evaluates those decipherments and eliminates the problematic identifications. It reveals the most acceptable transliteration of the inscription through a detailed analysis of the photograph of Kalbak-Taš I inscription taken and published by Tybykova et al. (2012). The author con-

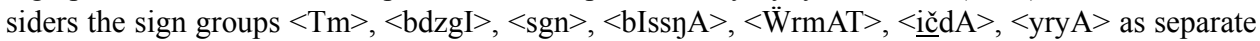
lexical units. The inscription is transcribed and translated here as yer bäygü ärmiš atam bädzägi äs̆gin bessinä ürmät ${ }^{l}[i]$ ičdä $y<i>r y \ddot{a}$ (...) 'The earth has been eternal. (This is) my father's ornament (inscription?). Without blowing to his ambling mare, from the court northwards (...)'.

Key words: Runic inscriptions, Old Turkic inscriptions, Mountainous Altai inscriptions, Kalbak-Taš I (A-23).

\section{Introduction}

There are several locations and various types of Old Turkic inscriptions. These inscriptions are generally inscribed on a flat and evened piece of rock as in the case of three well-known inscriptions, or on a piece of natural rock as in some Yenisei inscriptions. Some of those which were inscribed on natural rock pieces are composed of the inscriptions in the mountain and hill sides. The most renowned ones that contain these kinds of inscriptions are Kïzïl Kaya, Tepsey, Tayhar (Sertkaya and Harcavbay 2001: 313), Haya Baši, Arhanan (Aydın 2013: 147) and Kalbak Taš rocks.

Kalbak Taš rock complex, that carries the inscription A-23, is located at the 726th kilometre of the Čuy road leading to Mongolia over the Novosibirsk border. It consists 
of three facades. Facades I and II are near the western extremity of the mountain and Facade III is located on the southern rocky cliff. These three facades contain 31 pieces of old Turkic runic inscriptions (Tybykova et al. 2012: 69). Considering that 90 old Turkic runic inscriptions have been found so far in the Mountainous Altai region, it becomes apparent that the Kalbak-Taš subgroup constitutes one third of the Mountainous Altai inscriptions.

Kalbak-Taš I is located on the lower part of the first facade of the Kalbak-Taš rock complex. The inscription starts $18 \mathrm{~cm}$ above the ground and it is inscribed vertically from the bottom to the top. It contains just one line, the total length of which is $72.5 \mathrm{~cm}$. The heights of the signs in the inscription range from 1.6 to $6.5 \mathrm{~cm}$. (Tybykova et al. 2012: 70). As an orthographical feature, the inscription contains no separation mark.

Kalbak-Taš I was studied for the first time in 1984 by Nadeljajev. Further studies were put forward by Kyzlasov in 2002 and Tybykova et al. in 2012. In the study of Tybykova et al. (2012), all previous readings and interpretations of both the Kalbak Taš and the other Mountainous Altai inscriptions were evaluated and the transliterations, transcriptions and translations of all inscriptions were provided. However, when the study of Tybykova et al. and the subsequent ones are checked, it may be seen that not any considerable decipherment proposal has been reached in the literature except for the first sentence of the inscription. Furthermore, some readings and interpretations are grammatically and/or semantically invalid. The problematic issues that have emerged in the previous studies are: (1) The transliterations of Kalbak-Taš I given by those researchers do not harmonise with each other regarding some sign decipherments. (2) The previous researchers fail to determine the border of the meaningful lexemes correctly, since the inscription contains no separation mark. (3) The part coming after the first nine signs is either mistranscribed and mistranslated or completely left without evaluation.

This paper attempts to reconsider some problematic parts of Kalbak-Taš I and provides new readings and interpretations based on grammatical and semantic evidence. The paper is organised as follows: Section 1 is Introduction. In Section 2, the previous studies on the inscription are dealt with, respectively, to determine the actual glyph inventory of Kalbak Taš I inscription. In Section 3, a new reading proposal and explanations are presented. Finally, the lessons drawn from these findings are summarised in Section 4, the Conclusion.

\section{Glyph Inventory of Kalbak-Taš I (A-23)}

As stated above, Kalbak-Taš I has been studied by Nadeljajev, Kyzlasov and Tybykova et al. so far. When these studies are examined, it can be seen that Nadeljajev identified 39 signs, Kyzlasov 40 signs and Tybykova et al. 38 signs. Furthermore, the transliterations of these researchers include some remarkable differences.

In this section, Nadeljajev's (Nad.), Kyzlasov's (Kyz.) and Tybykova et al.'s (TNE) transliterations are given in a comparative table first. Then the data at hand are 
assessed by a thorough analysis of the partial images selected from the photograph (Tybykova et al. 2012: 70, Photo No. 44) of the inscription to eliminate the problematic identifications and to determine the most acceptable transliteration of the inscription. In the running text, angle brackets $<>$ stand for graphematic writings, while square brackets [ ] are used for reconstructions.

Signs 1-9: The first nine signs given by those researchers are almost the same except Nadeljajev:

Table 1

\begin{tabular}{|l|c|c|c|c|c|c|c|c|c|}
\hline & 1 & 2 & 3 & 4 & 5 & 6 & 7 & 8 & 9 \\
\hline Nad. & y & r & b & y & g & $\ddot{W}$ & r & m & W \\
\hline Kyz. & y & r & b & y & g & $\ddot{W}$ & r & m & s \\
\hline TNE & y & r & b & y & g & $\ddot{W}$ & r & m & $\check{s}$ \\
\hline
\end{tabular}

As can be seen in Table 1 above, Nadeljajev displays the ninth sign as $\langle\mathrm{W}\rangle$. However, the photograph of the inscription confirms the existence of a small and weak $<\check{\mathrm{s}}>$, as can be seen in Photos $2 \mathrm{a}$ and $2 \mathrm{~b}$ below:

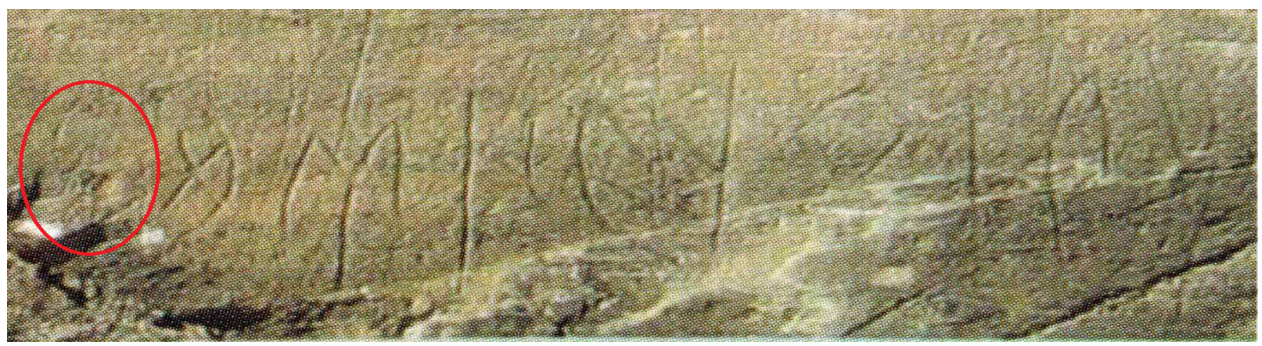

Photo 2a

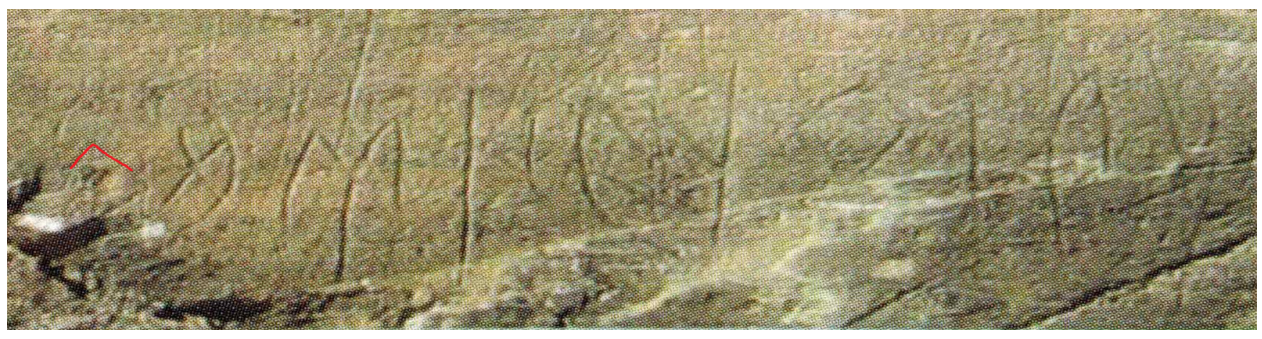

Photo $2 \mathrm{~b}$

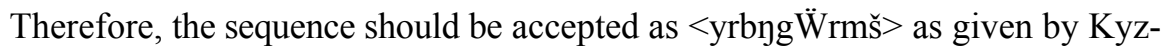
lasov and Tybykova et al. 
Signs 10-16: The mentioned sources displayed Signs $10-16$ as in Table 2 below:

\section{Table 2}

\begin{tabular}{|l|c|c|c|c|c|c|c|}
\hline & 10 & 11 & 12 & 13 & 14 & 15 & 16 \\
\hline Nad. & T & $\check{c}$ & $\mathrm{~b}$ & $\mathrm{~d}$ & $\mathrm{z}$ & $\mathrm{g}$ & $\mathrm{I}$ \\
\hline Kyz. & $\mathrm{T}$ & $\mathrm{K} / \check{\mathrm{s}}$ & $\mathrm{b}$ & $\mathrm{d}$ & $\mathrm{z}$ & $\mathrm{g}$ & $\mathrm{I}$ \\
\hline TNE & $\mathrm{T}$ & $\mathrm{m}$ & $\mathrm{b}$ & $\mathrm{d}$ & $\mathrm{z}$ & $\mathrm{g}$ & $\mathrm{I}$ \\
\hline
\end{tabular}

According to Table 2, the scholars have more or less consensus on the sequence starting with $<\mathrm{T}>$ and ending with $<\mathrm{I}>$. The problematic issue here is that the eleventh sign of the line is deciphered differently by all scholars: as $<\check{\mathrm{c}}>$ by Nadeljajev, as $<\mathrm{K}>$ or $<\check{\mathrm{s}}>$ by Kyzlasov and as $<\mathrm{m}>$ by Tybykova et al. If the photograph is checked, one may see that the eleventh sign is an $<\mathrm{m}>$, the upper left line of which has not been carved:

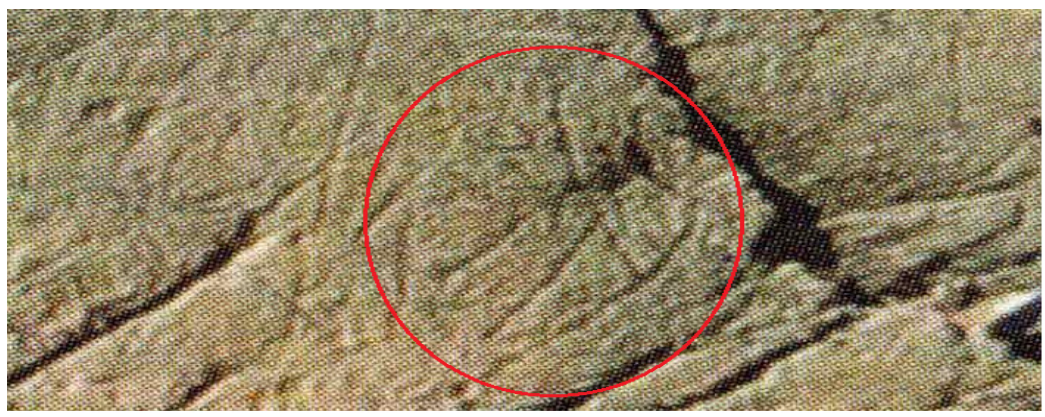

Photo 3a

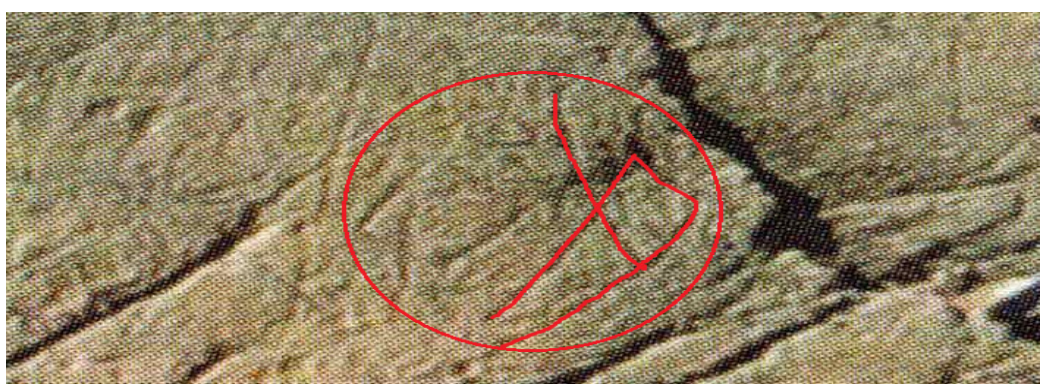

Photo $3 b$ 
But when the observer concentrates on the right half of the sign and ignores the existence of the other lines, it is possible to see the sign $<\check{\mathrm{c}}>$ here. In my opinion, that was what Nadeljajev saw at that point of the inscription:

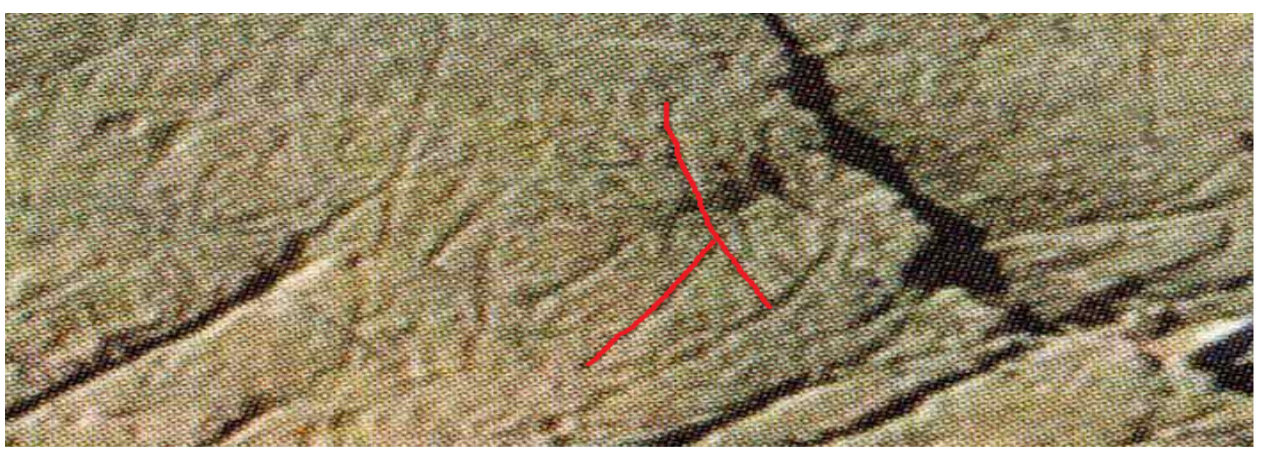

Photo 4

Signs 17-25: After the sixteenth sign of the inscription, the differences among the sign decipherments of the researchers increase (Table 3):

Table 3

\begin{tabular}{|l|c|c|c|c|c|c|c|c|c|}
\hline & 17 & 18 & 19 & 20 & 21 & 22 & 23 & 24 & 25 \\
\hline Nad. & $\mathrm{s}$ & $\mathrm{g}$ & $\mathrm{n}$ & $\mathrm{b}$ & $\mathrm{I}$ & $\mathrm{s}$ & $\mathrm{r} / \mathrm{lt}$ & $\mathrm{L}$ & \\
\hline Kyz. & $\mathrm{s}$ & $\mathrm{g}$ & $\mathrm{n}$ & $\mathrm{b}$ & $\mathrm{I}$ & $\mathrm{s}$ & $\mathrm{y} ?$ & $\mathrm{I} ?$ & $\mathrm{~A}$ \\
\hline TNE & $\mathrm{s}$ & $\mathrm{g}$ & $\mathrm{n}$ & $\mathrm{b}$ & $\ddot{\mathrm{W}} / \mathrm{I}$ & $\mathrm{s}$ & $\mathrm{y}$ & $\mathrm{g}$ & $\mathrm{A} / \mathrm{L}$ \\
\hline
\end{tabular}

The first difference here arose in Tybykova et al.'s publication. Those researchers were undecided about the twenty-first sign and they transliterated it as both $<\ddot{\mathrm{W}}>$ and $<\mathrm{I}>$. However, they preferred to draw an $<\ddot{\mathrm{W}}>$ in their illustration (Figure 1):

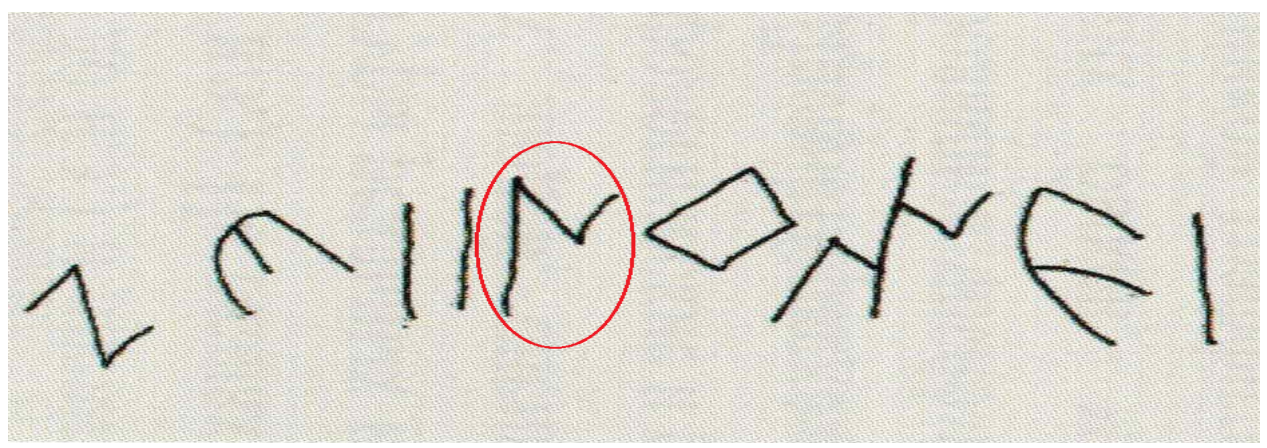

Figure 1. A partial image of the drawing No. 45 in Tybykova et al. 2012: 70 
What Tybykova et al. assumed as the small stroke of the sign $<\ddot{\mathrm{W}}>$ here was the upper part of a diagonal line which belonged to the surface of the rock on which Kalbak-Taš I was inscribed, as can be seen in Photos $5 \mathrm{a}$ and $5 \mathrm{~b}$ :

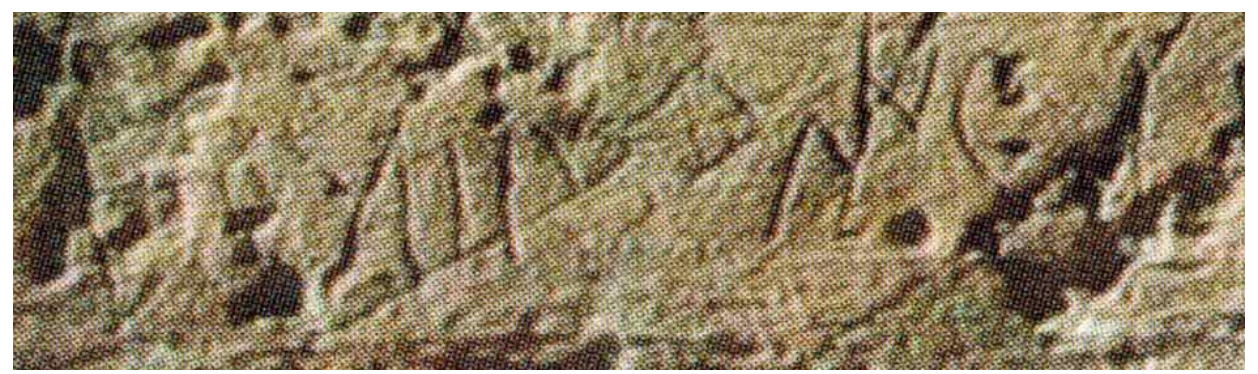

Photo 5a

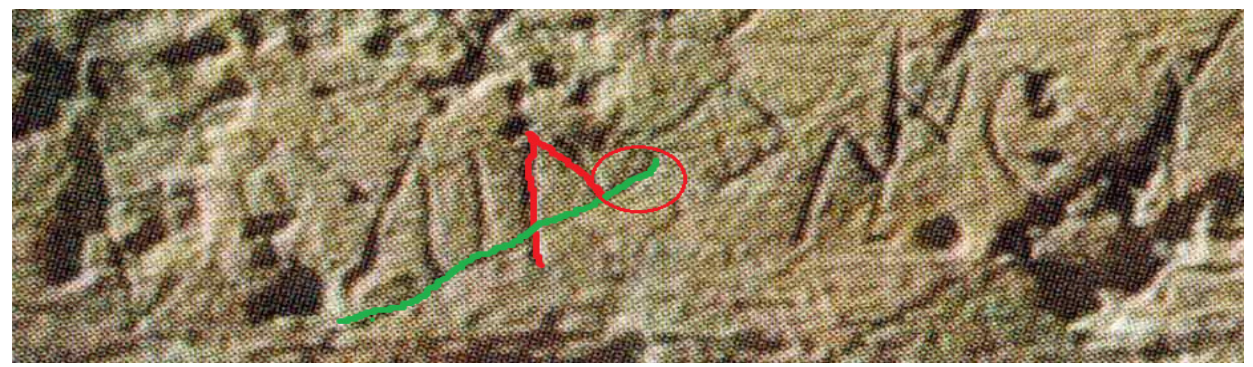

Photo 5b

Therefore, the twenty-first sign of the inscription should be taken as $\langle\mathrm{I}\rangle$, as in Nadeljajev's and Kyzlasov's works.

The twenty-second sign is not problematic. It is an $<_{\mathrm{s}}>$, as given by all researchers and as can be clearly seen in Photo 6:

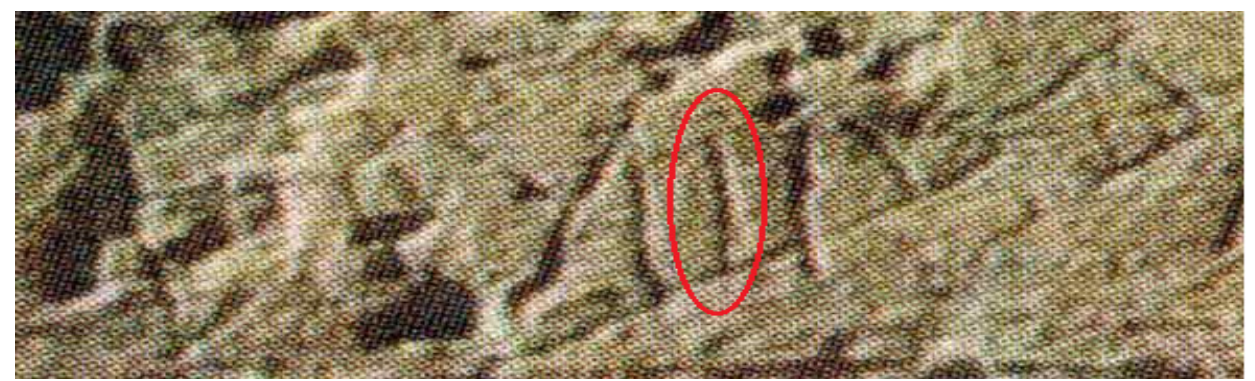

Photo 6

Before discussing the other signs, it will be useful to draw attention to a very important point. It should be noted that actually two $<\mathrm{s}>$ 'es were inscribed in the inscription: 


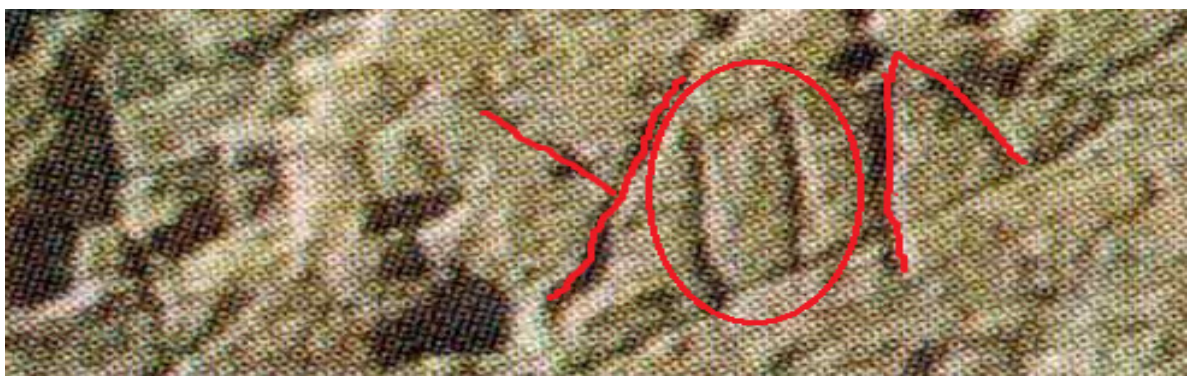

Photo 7

As a matter of fact, the existence of that second $<\mathrm{s}>$ was noticed and recorded for the first time by Tybykova et al. (Figure 2):

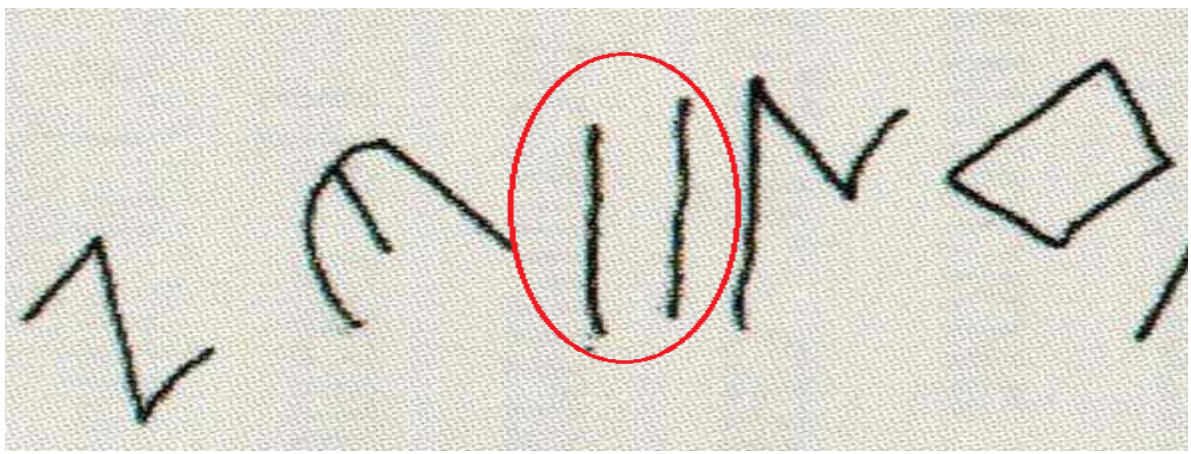

Figure 2. A partial image of the drawing No. 45 in Tybykova et al. 2012: 70

However, that second $<_{\mathrm{s}}>$ was excluded from their transliteration. Since the existence of the second $<\mathrm{S}>$ can clearly be proved by the photograph, it should be taken as the twenty-third sign of the inscription.

The following sign was identified as $<\mathrm{r}>$ or $<$ lt $>$ by Nadeljajev; $<$ n? $>$ by Kyzlasov and $<\mathrm{n}>$ by Tybykova et al. At this point, the sign $<\mathrm{n}>$ (turned $45^{\circ}$ clockwise) can be clearly seen in Photo 8 below:

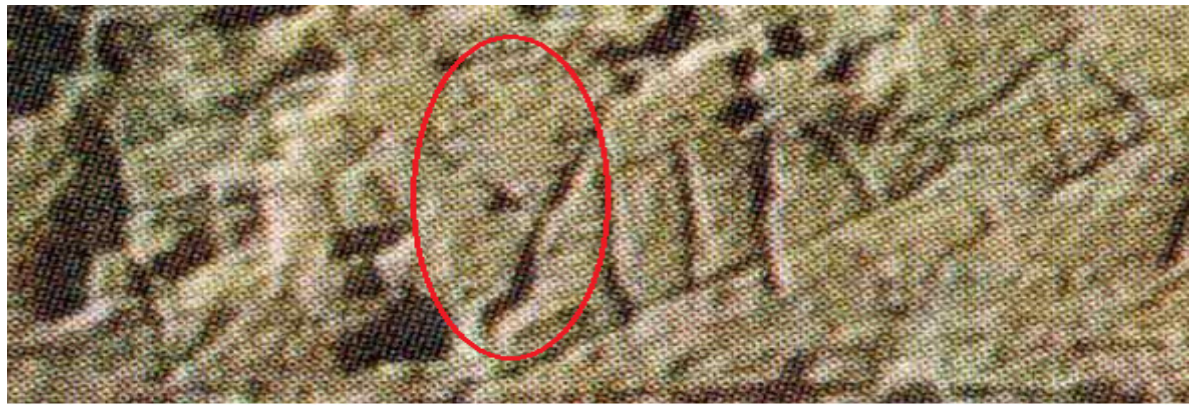

Photo 8 
This sign should be recorded as the twenty-fourth sign, not as the twenty-third one.

The last sign of this sequence was identified as $<\mathrm{L}>$ by Nadeljajev (Sign 24), as $<\mathrm{A}>$ by Kyzlasov (Sign 25) and as $<\mathrm{A}>$ or $<\mathrm{L}>$ (Sign 25) by Tybykova et al. Kyzlasov recorded an additional $<\mathrm{I}>$ (Sign 24) as a doubtful sign, after the $<\mathrm{y}>$ there. But the photograph of the inscription clearly proves that a mirrored $<\mathrm{A}>$ was inscribed as the twenty-fifth sign of the inscription:

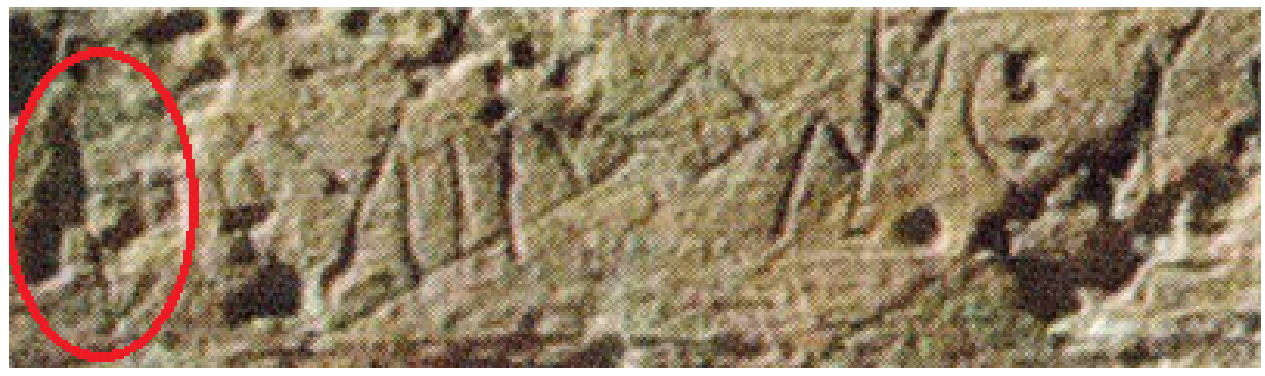

Photo 9a

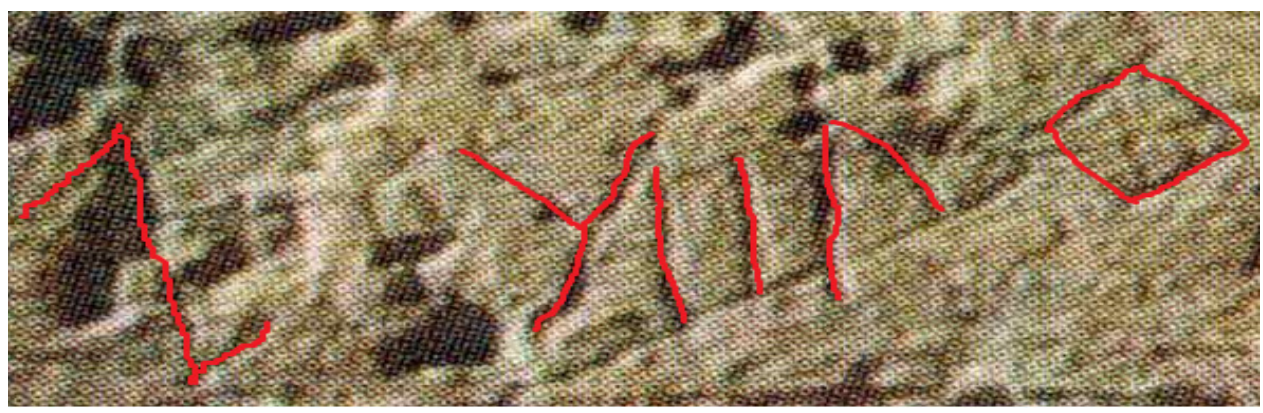

Photo $9 \mathrm{~b}$

Therefore, the sequence here should be accepted as $<\mathrm{bIss} \mathrm{A}>$ as is seen in Photo 9b. At this point, it is possible that the reader may mind why there is a huge space between the signs $<\mathrm{y}>$ and $<\mathrm{A}>$ while the other signs are relatively close to each other. The reader should note here that there is a quite deep cavity on the surface of the rock between the signs $<\mathrm{y}>$ and $<\mathrm{A}>$. Most probably, this cavity already existed on the surface of the rock even at the time when the inscription was inscribed and the scribe was not able to inscribe the sign $<\mathrm{A}>$ immediately after $<$ y $>$.

Tybykova's transliteration gives an optional $<\mathrm{g}>$ for the space between $<\mathrm{y}>$ and $<\mathrm{A}>$ (see above). However, it cannot be confirmed by the photograph (see Photo 9a). 
Signs 26-33: As for Signs 26-33, the researchers identified them as in Table 4.

\section{Table 4}

\begin{tabular}{|l|c|c|c|c|c|c|c|c|}
\hline & 26 & 27 & 28 & 29 & 30 & 31 & 32 & 33 \\
\hline Kyz. & $\ddot{\mathrm{W}}$ & $\mathrm{r}$ & $\mathrm{m}$ & $\mathrm{A}$ & $\mathrm{T}$ & $\underline{\mathrm{ic}} / \check{\mathrm{s}}$ & $\mathrm{d}$ & $\mathrm{A}$ \\
\hline TNE & $\ddot{\mathrm{W}}$ & $\mathrm{r}$ & $\mathrm{m}$ & $\mathrm{p}$ & $\mathrm{T}$ & $\underline{\mathrm{ic}} / \mathrm{g}$ & $\mathrm{d}$ & $\mathrm{A}$ \\
\hline Nad. & $\ddot{\mathrm{W}}$ & $\mathrm{r}$ & $\ddot{\mathrm{W}}$ & $\mathrm{p}$ & $\mathrm{T}$ & $\check{\mathrm{c}}$ & $\mathrm{d}$ & $\mathrm{A}$ \\
& $(25)$ & $(26)$ & $(27)$ & $(28)$ & $(29)$ & $(30)$ & $(31)$ & $(32)$ \\
\hline
\end{tabular}

The first problematic issue in this sequence is that the twenty-eighth sign of the inscription was identified as $<\ddot{\mathrm{W}}>$ by Nadeljajev. However, there is no doubt regarding the identity of this sign as can be seen on the photographs above. The twenty-ninth sign $<\mathrm{A}>$ and the thirty-first sign $<\underline{\mathrm{i}} \mathbf{\mathrm { c }}>$ can also be distinguished quite clearly in Photos $10 \mathrm{a}$ and $10 \mathrm{~b}$.

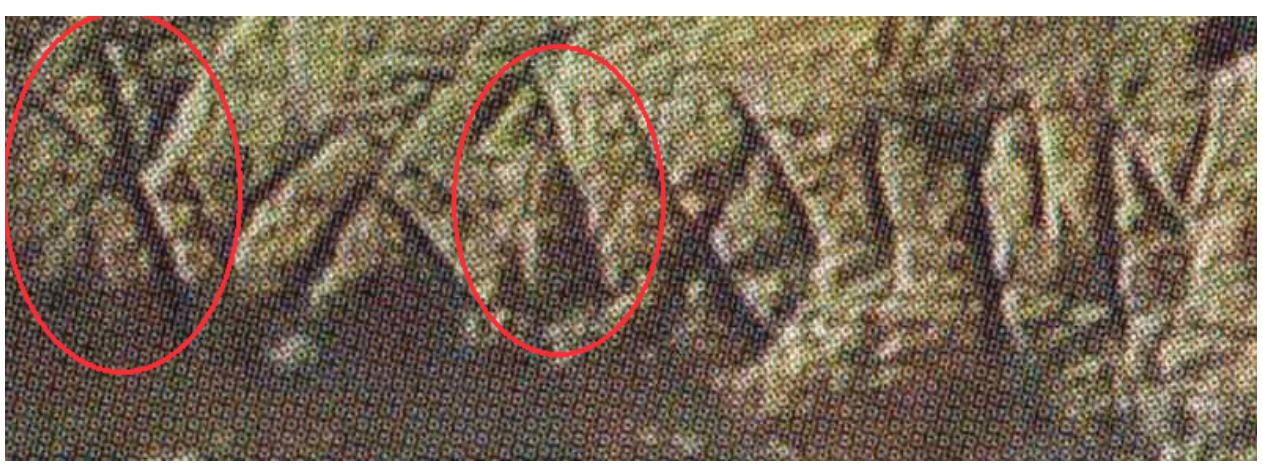

Photo 10a

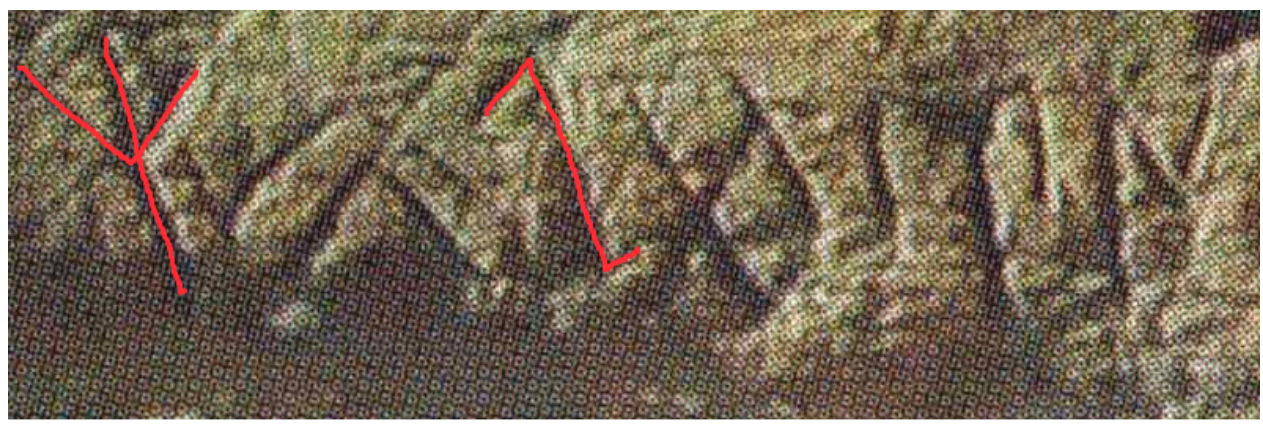

Photo $10 \mathrm{~b}$ 
As for the last part of the inscription (Sign 32 and the following ones), it cannot be seen clearly in the photograph of the inscription (Photo 11).

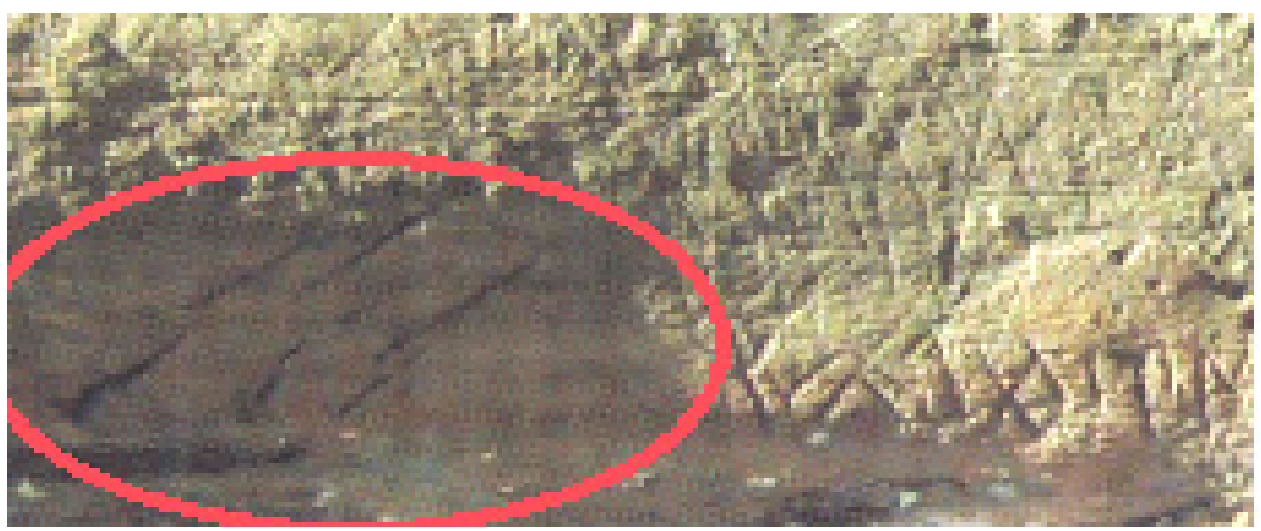

Photo 11

However, since all the researchers have consensus, the thirty-second and thirtythird signs can reliably be accepted as $\langle\mathrm{dA}\rangle$.

Signs 34 and the following ones: The last part of the inscription which cannot be seen in the photograph was identified by the researchers as follows:

\section{Table 5}

\begin{tabular}{|l|c|c|c|c|c|c|c|}
\hline & 34 & 35 & 36 & 37 & 38 & 39 & 40 \\
\hline Kyz. & $\mathrm{y}$ & $\mathrm{r}$ & $\mathrm{y}$ & $\check{\mathrm{s}} / \mathrm{A}$ & $\mathrm{s} / \mathrm{Y}$ & $\mathrm{p}$ & $\mathrm{g}$ \\
\hline TNE & $\mathrm{y}$ & $\mathrm{r}$ & $\mathrm{y}$ & $\mathrm{A}$ & $\mathrm{Y}$ & & \\
\hline Nad. & $\mathrm{y}$ & $\mathrm{r}$ & $\mathrm{y}$ & $\mathrm{s}$ & $\mathrm{A}$ & $?$ & $\mathrm{p}$ \\
& $(33)$ & $(34)$ & $(35)$ & $(36)$ & $(37)$ & $(38)$ & $(39)$ \\
\hline
\end{tabular}

Signs 34-36 are the same in all studies. However, the following one is deciphered as $<\breve{\mathrm{S}}>$ or $<\mathrm{A}>$ by Kyzlasov, as $<\mathrm{A}>$ by Tybykova et al. and as $<_{\mathrm{s}}>$ by Nadeljajev. In terms of meaning, it would be better to accept the sequence here as $\langle y r y A>$ (see explanations below).

In the remaining part of the inscription, two or three additional signs are inscribed. But since they are differently identified by the researchers and they cannot be clearly seen on the photograph of the inscription (see Photo 11 above), I prefer giving them as (...) in my transliteration.

Finally, according to the evidence provided by the photograph, the most reliable transliteration of the inscription should be accepted as follows:

yrbng ẄrmšTmbdzgIsgnbIssnAẄrmATị̌dAryA(...) 


\section{A New Reading Proposal and Explanations}

As stated above, Kalbak Taš I does not contain any separation mark. In such case, it is of vital importance to determine the borders of the lexical units to read and interpret the inscription correctly. In my opinion, the lexical units of the inscription should be separated as $<$ yr $>$, <byg $\ddot{\mathrm{W}}>,<$ rmš $>,<\mathrm{Tm}>,<$ bdzgI $>,<$ sgn $>,<$ bIssnA $>,<$ WrmAT $>$, $<\underline{\mathrm{ičd}} \mathrm{A}>,<\mathrm{yryA}>,(\ldots)$. Accordingly, I propose the inscription to be transcribed and translated as follows:

yer bäygü ärmiš atam bädzägi äšgin bessinä ürmät ${ }^{1}[i]$ ičdä y[i]ryä (...)

'The earth has been eternal. (This is) my father('s) ornament (inscription?).

Without blowing to his ambling mare, from the court northwards (...)'.

A further explication of the reasons for my reading and interpretation is stated in the following lines. Since the first three words were correctly read and translated by Kyzlasov and Tybykova et al. before, it is better to start with the fourth one:

$<$ Tm $>$ atam

In my opinion, Signs 10-11, which occur here as the fourth word of the inscription, give the word $a t a+m$ 'my father'. The word atam is inflexed in zero-marked genitive and it modifies the following noun bädzägi.

\section{$<$ bdzgI $>=$ bädzägi}

Signs 12-17 may be read as bädzägi and they occur here as the fifth word of the inscription. The lexeme $b a \ddot{a} d z \ddot{a} g$ has not been attested elsewhere in Old Turkic, but it is no doubt a deverbal noun from bädzä- 'to adorn' (Clauson 1972: 310a). This word is modified by the previous word and the noun phrase here stands as the second sentence of the inscription. Compared to the verb from which it was derived, the word $b \ddot{a} d z \ddot{a} g$ would mean 'ornamentation' primarily. However, since there is no ornamentation on the surface of the rock, maybe it would be better to interpret it as a lexeme meaning 'inscription (?)'. At this point, the reader may mind why there is a need to form such a word as *bädiz+ä-g if bädiz is already available with the same meaning. However, the reader should note that those kinds of derivations were in use in Old Turkic. For example ornay 'place, seat' (Clauson 1972: 234b) < orna- 'to take one's place, establish oneself (with some extended meanings)' (Clauson 1972: 235b) < orun 'place; high place, throne' (Clauson 1972: 233a); ödläg 'time' < *ödlä- < öd 'time' (Clauson 1972: 55b) ${ }^{1}$; aša I 'eating, food' (Clauson 1972: 259a) < aša- 'to eat' (Clauson 1972: 256b) < aš 'food' (Clauson 1972: 253b).

${ }^{1}$ According to Clauson the noun ödläg is a deverbal noun from * $\ddot{o d l a ̈}$-, which is a denominal verb from $\ddot{o} d$. He states here that there is no obvious difference in meaning between $\ddot{o} d$ and ödläg. 
$<$ sgn $>=$ äšgin

Signs 18-20 can be read as äšgin 'a trot, amble; trotting, ambling' and this lexeme is used both as a noun and as an adjective in Old Turkic. According to the data we have, its attributive use is first attested in 13th-century Küpčak (see äšgin I, Clauson 1972: 260b). However, even the nominal use of the lexeme äšgin is rarely attested in Old Turkic and we do not have broad data to use for a detailed comparison. Therefore, the possibility that it may have been used as an attributive in Old Turkic cannot be completely excluded. In Kalbak Taš I, it seems to modify the following noun be 'mare' (see below) and these two lexemes seem to form an adjective phrase meaning 'ambling mare'.

\section{$<$ bIssyA $>=$ bessinä}

Signs 21-26 can be read as bessiyä < be $+s s i+\eta \ddot{a}$ 'to his mare' (noun stem + third person possessive + dative case). In item be: 2 'mare', Clauson (1972: 291b) states that this lexeme survives in many Turkic language groups and the surviving forms point to original be: with long-closed $e$. Therefore, it should be noted that the sign $<\mathrm{I}>$ represents closed /e/ here (a common orthographical feature in runic script). As for the consonant gemination $+s I>+s s I$ in the third person possessive suffix, it occurred as a compensatory phonological process due to the shortening of the long vowel in the noun stem. This process has been very common both in historical and modern Turkic languages. ${ }^{2}$

\section{$<\ddot{\mathbf{W}} \mathbf{r m A T}>=$ ürmät $^{1}[\mathbf{i}]$}

The intermediate sequence $<$ WrmAT $>$, which occurs between the sign groups $<$ bIssnA $>$ and $<\underline{\mathrm{ic} d \mathrm{~A}}>=\underline{i c} d \ddot{a}$ (see below), is the most problematic issue in the inscription and there is not any considerable decipherment proposal in literature. The most obvious problem to deal with is the fact that front vowel signs and back $<\mathrm{T}>$ co-occur in the sequence. Prima facie, this sequence seems to violate the orthographical rules valid in the runic script. However, in runic inscriptions there are relatively many examples of back and front consonant signs used in non-canonic ways. For example $<$ yrdKI $>=$ yerdäk ${ }^{l} i$ in Kalbak Taš XXII (Tybykova et al. 2012: 89); $<$ WzzDA $>=\ddot{o z} d^{l} \ddot{a}$ in E-7/4 (Kormušin 1997: 208), <ytA > = y ït $a$ in E-28/5 (Kormušin 1997: 80), <tWGDm> = $t^{2}$ uydïm in E-29/5 (Kormušin 1997: 71), <bWnWm $>=b^{2}$ uyum in E-46/4 (Kormušin 1997: 224), $<\mathrm{KIrK}>=q \ddot{i r}{ }^{2} q$ in E-98/2 (Kormušin 1997: 121); $<\mathrm{yIL}>=y^{2} \ddot{i l}$ in O 12 (Tekin 2003: 32), <yILKI $>=y^{2} \ddot{i l l q} \ddot{i}$ in KT SW (Tekin 2003: 32), $<$ sIGTAmš $>=$ $s^{2} \ddot{i}$ tamï̌s BQ E 5 (Tekin 2003: 32).

In my opinion, the signs $\langle\ddot{\mathrm{W}} \mathrm{r}>$ in the sequence give the Old Turkic verb $\ddot{u} r-I$

'to blow (into something dative)' (Clauson 1972: 195b). The Old Turkic verb ür- is

\footnotetext{
${ }^{2}$ For detailed information, see Tekin 1995: 148-153.
} 
used with the dative case as stated by Clauson and as it is in our instance. I propose the following $<\mathrm{mAT}>$ to be taken as the negative converb $-m A t^{1}[I]$, with the reconstruction of the final [I]. That the word-final vowel is not inscribed seems to violate the orthographical rules (see previous paragraph). However, when the sign groups are written adjacently (without a separation mark in between) in the runic script, sometimes the word-final vowel is not represented. For example, $<$ yrdk $>=$ yerdäk $[i]$ in Kalbak Taš XXII (Tybykova et al. 2012: 89) and $<\mathrm{kÜrtl}>=k \ddot{r} r t l[\ddot{a}]^{3}$ in E-10/5 (Kormušin 1997: 235). ${ }^{4}$

As it is known, all converbs are negated with the suffix $-m A t I$ or $-m A t I n$ in Old Turkic. The form $-m A t I$ is more rare and it is attested only in KT E/10, T II E/2 and ŠU E/3 (Erdal 2004: 314).

As for the meaning of 'to blow into (the nostrils of) a horse', it is known as a way to introduce yourself to it in horse training ${ }^{5}$. However, the man to whom Kalbak Taš I inscription was dedicated behaved without doing it.

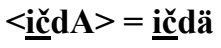

Signs 32-34 may be read and interpreted as $i \check{c}+d \ddot{a}$ 'from the court'. The lexeme $i \check{c}$, which basically means 'the interior, or inside (of something)' (Clauson 1972: 17a), early acquired a number of specific connotations, e.g. 'the interior of a household, esp. a royal household' (Clauson 1972: 17b).

In the Orkhon Turkic, the syllabic sign $<\underline{\mathrm{ic}}>$ is rarely used to designate the initial sound group $i \check{c}$ - as stated and exemplified by Tekin (2003: 36). The sign $\langle\underline{\mathrm{ic}}>$ in Kalbak Taš I seems to be the unique ${ }^{6}$ instance in the whole corpus of the Turkic runic inscriptions in the Mountainous Altai region. Therefore, it is not possible to make any further explication about its use in this subgroup.

\section{$<$ yryA $>=$ y[i]ryä}

I assume that the sign group <yryA> gives the word $y[i] r y \ddot{a}$ 'northwards' and this word is the palatalised counterpart of yïrya 'in the north' in KT S/1, E/14; BQ E/12 (Clauson 1972: 973b) etc. Since the spelling of the noun stem is erratic in Old Turkic (in Orkhon yïr; in Old Uighur ir yir, cf. Clauson 1972: 954b), the variation y[i]ryä seems not implausible. Furthermore, it is possible to find additional instances in the Turkic runic script that the sign $<\mathrm{I}>$ in the first syllable was not inscribed: $<$ btdm $>=$ b[i]tidim in Kalbak Taš XV (A-33) (Tybykova et al. 2012: 80), <blgsI $>=b$ [i]lgäsi in $\mathrm{T} 7,<\mathrm{tldm}>=t$ [i]lädim in T 23 (Tekin 2003: 28), <trg $>=t$ [i] rig in E-53 (Kormušin 1997: 280), $<\mathrm{YTA}>=y$ [i]]t $a$ in E-32 (Kormušin 1997: 117), etc.

\footnotetext{
${ }^{3}$ This word is attested in the title $<\mathrm{kÜrtlKn}>=k \ddot{r} r t l[\ddot{a}]$ qan.

${ }^{4}$ For additional instances, see Tekin 2003: 30-31.

${ }^{5}$ For detailed information, see http://www.dba-oracle.com/horse manners.htm 05.12.2018

${ }^{6}$ There might be one more suspicious instance in the inscription Mendur-Sokkon III (A-11) according to the corpus in Tybykova et al. 2012: 133.
} 
Finally, it is better to touch on the earlier transcriptions and translations of the inscriptions. The first researcher Nadeljajev (1984) transcribed and translated Kalbak Taš I inscription as follows: (1) Jar-bangu ärim! Otači äb äd: (2) aza ig isigin bisär al, ürüp (3) at! Ač äd! Jär-Jiš -(ti)p. '(Сказ)ал: “Земля-вечное бытие! Облагодетельствуй дом (семью) лекарятравника: Рятикратно возьми; жар бесовской болезни, подуй-изгони! Сотвори благодать.”' (Tybykova et al. 2012: 70, from Nadeljajev 1984: 94-95). This Russian translation can be translated to English as follows: '[(He said th)at: The beings of the eternal-place! Do a favour for the physician's home (family): Take it five times, the heat of the demonic disease, (and) blow it out! Create grace!].' This first study on Kalbak-Taš I is full of grammatical and semantic mistakes which will not be dealt with here respectively. However, to say something, Nadeljajev's misinterpretations stem from the fact that not only could he not discern the borders of the words and sentences correctly, but he also tended to interpret the inscription as a healing text.

Kyzlasov (2002) just made the transcription and transliteration of the first sixteen signs and left the other half of the inscription without evaluation: Yer bängü ärmiš taš(?) bädizgi... 'Земля-вечно была, на внешнем (?) изображении находящийся...' [The earth has been eternal, ... being on the external image ...] (Tybykova et al. 2012: 70, from Kyzlasov 2002: 63).

Tybykova et al. (2012: 70) transcribed and translated the inscription partially, either: Yer bäygü ärmiš... bädizig..... ür... 'Оказывается, земля-вечная... изображение... вырезать' [= It turns out (that) the earth (has been) eternal... the image+acc. ... to cut....].

The new readings which are proposed in this paper provide an alternative to the former readings. However, it is open to any discussion and the author will welcome any kind of criticism.

\section{Conclusion}

In this paper Kalbak-Taš I inscription was re-evaluated especially from the vantage point of orthography. Problematic issues that have emerged in previous studies were treated in detail and new solutions were proposed for some problematic sequences. The author considered the sign groups $<\mathrm{Tm}>$ and $<$ bdzgI $>$ as the second sentence of the inscription and proposed to read and interpret it as atam bädzägi '(This is) my father's inscription(?)'. The following three lexemes, $<$ sgn $>$, $<$ bIssyA $>$ and $<$ ẄrmAT $>$ were suggested to be read as äšgin 'trotting, ambling', bessipä 'to his mare', $\ddot{\text { urmät }}{ }^{1}[i]$ 'without blowing'. The remaining sequence $<\underline{\mathrm{ic}} \mathrm{c}$ AyryA $>$ was treated as two separate lexical units as $<\underline{\mathrm{ic}} \mathrm{dA}>=\underline{i c} d \ddot{a}$ 'from the court' and $<\mathrm{yryA}>=y[i] r y \ddot{a}$ 'northwards'. Finally, those last five lexemes were evaluated as an incomplete sentence as äšgin bessiyä ürmät ${ }^{l}[i]$ ičdä y[i]ryä (...) 'Without blowing to his ambling mare, from the court northwards (...)'. 


\section{Abbreviations}

BQ: Bilgä Qayan inscription

E: Eastern face

E-: Yenisei

KT: Köl Tegin inscription

O: Ongi inscription

\author{
S: Southern face \\ SW: Southern-West face \\ ŠU: Šinä Usu \\ T: Tuńuquq inscription
}

\section{References}

AYDIN, Erhan 2013. 'Hoyto Tamır (Tayhar Çuluu) Yazıtlarının Türkçenin Söz Varlığına Katkıları [The contributions of the Hoyto-Tamyr (Taihar Čuluu) Inscriptions to Turkic vocabulary].' In: Hatice Şirin USER and Bülent GüL (eds.) Osman Fikri Sertkaya Armağanı [Festschrift for Osman Fikri Sertkaya]. [Turkish Culture Research Institute Publications.] Ankara: Türk Kültürünü Araştırma Enstitüsü Yayınları, 147-152.

Clauson, Gerard 1972. An Etymological Dictionary of Pre-Thirteenth-Century Turkish. Oxford: Clarendon Press.

ERDAL, Marcel 2004. A Grammar of Old Turkic. Leiden and Boston: Brill.

KormuŠin, I. V. [КОРмУшин, И. В.] 1997. Тюркские енисейские эпитафии. Тексты и исследования. Москва: Наука.

KyZlasov, I. L. [КЫЗЛАСОВ, И. Л.] 2002. Памятники рунической письменности Горного Алтая. Часть I. Горно-Алтайск: ГАГУ.

NAdelJAJeV, V. М. [НАДЕЛЯЕВ, В. М.] 1984. 'Древнетюркские надписи Горного Алтая.' In: Майя И. ЧЕРЕМИСинА (ред.) Алтайский язык на современном этапе его развития. Горно-Алтайск: АН СССР, 81-103.

Sertkaya, O. F. and S. Harcavbay 2001. 'Hoyto-Tamir (Mogolistan)'dan Yeni Yazıtlar (Ön Neşir) [New inscriptions from Hoytu Tamir/Mongolia (preliminary publication)].' Türk Dili Araştırmaları Yıllığı-Belleten [Yearbook of Turkic Studies-Belleten] 2000: 313-346.

Tekin, Talat 1995. Türk Dillerinde Birincil Uzun Ünlüler [Primary long vowels in the Turkic languages]. Ankara: Simurg.

Tekin, Talat 2003. Orhon Türkçesi Grameri [A grammar of Orkhon Turkic]. [The Serial of Researches in Turkic Languages 9.] İstanbul: Türk Dilleri Araştırmaları Dizisi.

Tybykova, L. N., I. A. Nevskaja, and M. ERdal [ТыБЫковА, Л. Н., Невская, И. А., ЭрДАЛ, М.] 2012. Каталог древнетюркских рунических памятников Горного Алтая. Горно-Алтайск: ГАГУ. 
